\title{
Frequent horizontal and mother-to-child transmission may contribute to high prevalence of STLV-1 infection in Japanese macaques
}

\author{
Megumi Murata', Jun-ichirou Yasunaga ${ }^{2,3}$, Ayaka Washizaki', Yohei Seki ${ }^{1}$, Madoka Kuramitsu', Wei Keat Tan', \\ Anna Hu ${ }^{1}$, Kazu Okuma ${ }^{4}$, Isao Hamaguchi ${ }^{4}$, Takuo Mizukami ${ }^{4}$, Masao Matsuoka ${ }^{2,3}$ and Hirofumi Akari ${ }^{1,5^{*}}$ (D)
}

\begin{abstract}
Background: Simian T-cell leukemia virus type 1 (STLV-1) is disseminated among various non-human primate species and is closely related to human T-cell leukemia virus type 1 (HTLV-1), the causative agent of adult T-cell leukemia and HTLV-1-associated myelopathy/tropical spastic paraparesis. Notably, the prevalence of STLV-1 infection in Japanese macaques (JMs) is estimated to be $>60 \%$, much greater than that in other non-human primates; however, the mechanism and mode of STLV-1 transmission remain unknown. The aim of this study is to examine the epidemiological background by which STLV-1 infection is highly prevalent in JMs.
\end{abstract}

Results: The prevalence of STLV-1 in the JMs rearing in our free-range facility reached up to 64\% (180/280 JMs) with variation from 55 to 77\% among five independent troops. Anti-STLV-1 antibody titers (ABTs) and STLV-1 proviral loads (PVLs) were normally distributed with mean values of 4076 and $0.62 \%$, respectively, which were mostly comparable to those of HTLV-1-infected humans. Our initial hypothesis that some of the macaques might contribute to frequent horizontal STLV-1 transmission as viral super-spreaders was unlikely because of the absence of the macaques exhibiting abnormally high PVLs but poor ABTs. Rather, ABTs and PVLs were statistically correlated ( $p<0.0001)$, indicating that the increasing PVLs led to the greater humoral immune response. Further analyses demonstrated that the STLV-1 prevalence as determined by detection of the proviral DNA was dramatically increased with age; $11 \%, 31 \%$, and $58 \%$ at 0,1 , and 2 years of age, respectively, which was generally consistent with the result of seroprevalence and suggested the frequent incidence of mother-to-child transmission. Moreover, our longitudinal follow-up study indicated that 24 of 28 seronegative JMs during the periods from 2011 to 2012 converted to seropositive (86\%) 4 years later; among them, the seroconversion rates of sexually matured ( 4 years of age and older) macaques and immature macaques (3 years of age and younger) at the beginning of study were comparably high ( $80 \%$ and $89 \%$, respectively), suggesting the frequent incidence of horizontal transmission.

Conclusions: Together with the fact that almost all of the full-adult JMs older than 9 years old were infected with STLV-1, our results of this study demonstrated for the first time that frequent horizontal and mother-to-child transmission may contribute to high prevalence of STLV-1 infection in JMs.

Keywords: STLV-1, Japanese macaques, Prevalence, Antibody titer, Proviral load, Mother-to-child transmission, Horizontal transmission

*Correspondence: akari.hirofumi.5z@kyoto-u.ac.jp

${ }^{1}$ Center for Human Evolution Modeling Research, Primate Research Institute, Kyoto University, 41-2 Kanrin, Inuyama 484-8506, Japan

Full list of author information is available at the end of the article

\section{Background}

Primate T-cell leukemia virus is classified into the Deltaretrovirus genus, which includes simian T-cell leukemia virus (STLV) and human T-cell leukemia virus 
(HTLV). The first human retrovirus, HTLV-1, was identified in 1980 [1, 2], even though the disease entity of adult T-cell leukemia (ATL) had been described in Japan before the identification of this virus [3]. Eventually, HTLV-1 was found to be the causative agent of not only ATL but also HTLV-1-associated myelopathy (HAM)/ tropical spastic paraparesis (TSP) [2, 4-6]. It is estimated that $10-20$ million people worldwide are infected with HTLV-1 [7]. HTLV-1 is endemic in southern Japan, the Caribbean, Central and South America, and intertropical Africa $[7,8]$. An estimated one million people in Japan are thought to be HTLV-1 carriers, corresponding to $1 \%$ of the total population $[7,9,10]$. In most cases, HTLV-1 infection remains asymptomatic, whereas $5 \%$ of the carriers develop ATL or HAM/TSP [11-18].

As a counterpart of HTLV, STLV is prevalent among a variety of non-human primates in Asia and Africa but not in America [19-23]. STLV-1 and STLV-2 are closely related with HTLV-1 and HTLV-2 [24-26]. A third subspecies, STLV-3, was isolated from an Eritrean sacred baboon (Papio hamadryas) and a red-capped mangabey (Cercocebus torquatus) [27, 28]. A recent report showed that STLV-4 was isolated from gorillas and that the virus was endemic to gorillas [29]. It has been reported that STLVs originated from African non-human primates are pathogenic to the natural hosts and are associated with leukemia/lymphoma [30-33]. The zoonotic STLV transmission to humans is likely caused by hunting and severe bites of non-human primates [20, 34-38].

Japanese macaques (JMs: Macaca fuscata) inhabit widespread of Japan except Hokkaido and Okinawa. Watanabe et al. reported that the sequence homology of JM STLV-1 genome to that of HTLV-1 was 90\% [24]. Given this genetic similarity, it had been suspected that zoonotic STLV-1 transmission might be, at least in part, the cause of HTLV-1 dissemination among Japanese. However, subsequent analysis between HTLV-1 isolated from Japanese and STLV-1 from JMs demonstrated that the STLV-1 was phylogenetically distinct from the HTLV-1 [39]. Furthermore, no geographical deviation in terms of the distribution of STLV-1-infected JMs is observed, which is in contrast with the case of HTLV1 -infected Japanese [40, 41]. From these findings, it is concluded that the HTLV-1 is originated in Mongoloid people moving from North Asia but not from the JM STLV-1 [39, 42].

Notably, a high proportion (60\% on average) of JMs is reportedly infected with STLV-1, whereas the prevalence of STLV-1 in other natural hosts among non-human primates, including Asian macaques, is generally much lower [19, 41, 43-53]. The reason for the abnormally high prevalence still remains unknown. In this study we sought to examine the epidemiological background as well as mechanism and mode of the STLV-1 transmission by which STLV-1 is highly prevalent among JMs.

\section{Methods \\ Animals}

JMs bred and reared in the free-range facility of the Primate Research Institute, Kyoto University (KUPRI) were used in this study. All the troops were isolated and had no physical connection with each other. All animal experiments were approved by the Animal Welfare and Animal Care Committee of KUPRI (approval numbers: 2014-092, 2015-040, and 2016-135) and were conducted in accordance with the Guidelines for Care and Use of Nonhuman Primates (Version 3) by the Animal Welfare and Animal Care Committee of KUPRI.

\section{Preparation of plasma and peripheral blood mononuclear cells (PBMCs)}

Blood samples were collected from JMs at the routine health checkups carried out during the periods from 2011 to 2012 and from 2015 to 2016 under ketamine anesthesia with medetomidine, followed by administration of its antagonist, atipamezole, at the end of the procedure. PBMCs were separated from blood samples with Ficoll-paque PLUS (GE Healthcare, Buckinghamshire, UK) by density gradient centrifugation. Plasma and PBMCs were frozen at $-80^{\circ} \mathrm{C}$ until use.

\section{Titration of the STLV-1-specific antibody}

Plasma samples were evaluated for STLV-1-specific antibody titers (ABTs) with a particle agglutination (PA) assay using Serodia-HTLV-1 (Fujirebio Inc. Tokyo, Japan) as previously described [52]. The plasma cut-off titer was a 1:16 dilution. In case of the macaques whose blood samples were positive for the antibody while negative for the proviral DNA were retested for the PA assay with and without absorption procedure according to the manufacturer's instructions. Only the individuals whose antibody positivity was confirmed by the absorption procedure were indicated as positive for the antibody while negative for the proviral DNA.

\section{Quantification of STLV-1 proviral DNA loads (PVLs)}

Cellular DNA was purified from PBMCs via a QIAamp DNA Blood Mini Kit (QIAGEN, Hilden, Germany), according to the manufacturer's instructions. The DNA samples were employed for the measurement of STLV-1 PVLs via a real-time PCR of the STLV-1 tax and RAG1 genes of JMs as previously described [52]. PCR was performed using Thunderbird Probe qPCR mix (Toyobo, Osaka, Japan). The following primers and probes were used: for RAG1, RAG1-2F (CCCACCTTGGGACTC AGTTCT), RAG1-2R (CACCCGGAACAGCTTAAA 
TTTC), and a RAG1 probe (5'-FAM CCCCAGATG AAATTCAGCACCCATATA TAMRA-3'); for tax, STLV-1 tax-F2 (CTACCCTATTCCAGCCCACTAG), STLV-1 tax-R3 (CGTGCCATCGGTAAATGTCC), and an STLV-1 tax probe (5'-FAM CACCCGCCACGCTGA CAGCCTGGCAA TAMRA-3'), respectively. Copy number of STLV-1 proviral DNA per cell was standardized with that of the RAG1 gene. The detection limit of PVLs was $0.01 \%$.

\section{Sequence analysis of STLV-1 $3^{\prime}$ LTR, tax and env regions}

The $3^{\prime}$ LTR, tax and env regions of the viral genome were amplified by using KOD-FX neo polymerase kit (Toyobo, Osaka, Japan) according to the manufacturer's protocol. The thermal cycle condition for $3^{\prime}$ LTR and env region was as follows; for 1 st PCR, $94{ }^{\circ} \mathrm{C}$ for 2 min followed by the 5 cycles of $98^{\circ} \mathrm{C}$ for $10 \mathrm{~s}$ and $68^{\circ} \mathrm{C}$ for $5 \mathrm{~min}$, and the 23 cycles of $98{ }^{\circ} \mathrm{C}$ for $15 \mathrm{~s}, 60{ }^{\circ} \mathrm{C}$ for $15 \mathrm{~s}$, and $68^{\circ} \mathrm{C}$ for $5 \mathrm{~min}$. For 2 nd PCR, $94{ }^{\circ} \mathrm{C}$ for $2 \mathrm{~min}$ followed by the 45 cycles of $98^{\circ} \mathrm{C}$ for $15 \mathrm{~s}, 60^{\circ} \mathrm{C}$ for $15 \mathrm{~s}$, and $68^{\circ} \mathrm{C}$ for $4 \mathrm{~min}$. For tax region, $94{ }^{\circ} \mathrm{C}$ for $2 \mathrm{~min}$ followed by the 50 cycles of $98^{\circ} \mathrm{C}$ for $15 \mathrm{~s}, 60^{\circ} \mathrm{C}$ for $15 \mathrm{~s}$, and $68^{\circ} \mathrm{C}$ for $2 \mathrm{~min}$.

PCR products were purified using QIAquick 96 PCR purification kit (QIAGEN, Hilden, Germany). The amplified fragments were directly sequenced by using BigDye ver 3.1 cycle sequencing kit (Applied Biosystems, Foster City, USA) and an Applied Biosystems 3730 DNA analyzer. Alignment of the determined sequences was analyzed by genetyx software. The following primers were used; for 3'LTR region; 7487F (CCCAGAGAACCTCTA AGACCCT), 8937R (TCAGACGTGAATGAAAGG GAAAG), and sequencing; 8152F (CAAGGCCTACCA TCCCTCTT), and for tax region, 1st PCR primers; 5021F (GGAAAGGACCACAGGARGC), 8937R (TCA GACGTGAATGAAAGGGAAAG), 2nd PCR primers; 5524F (CTTAGGATGCCAATCATGGA), 8619R (CCT GTTGTTTTATTGAGCTGTATGC), and sequencing; 7487F (CCCAGAGAACCTCTAAGACCCT) and 7742R (TACATGCAGACAACGGAGTTTCC), and for env region, 1st PCR primers; 3158F2 (CCCAGGACAAAA CTCARCAA), 7412R2 (CCGARCATAGTCCCCCAG
AGA), 2nd PCR primers; 4173F3 (CCTGCCCCGCCT ACTATCRC), 6672R (AAGCAATGTGGTCGCAGT AAC), and sequencing; 5012F (GGAAAGGACCACAGG ARGC), 5524F (CTTAGGATGCCAATCATGGA), 5975F (CCCCACCTGACGYTACCATT), respectively.

\section{Statistical analyses}

We tested the normal distribution of the data and applied parametric or non-parametric methods according to the experiment. Pearson's correlation coefficient was employed for correlation of two parameters, and twotailed Student's t-tests were employed for comparison of two groups. For multiple comparisons with more than two groups, a one-way ANOVA with Tukey's multiple comparison test was used.

\section{Results}

To validate the STLV-1 prevalence in JMs, we first examined for positivity of the anti-STLV-1 antibody in plasma of $280 \mathrm{JMs}$ from five independent troops originating from inhabitants of different areas in Japan. The plasma samples were obtained from JMs at the routine health checkups during the period from 2015 to 2016 . We found that 180 of 280 macaques (64\%) were seropositive for STLV-1 (Table 1), which was generally consistent with previous reports $[41,43,44,52]$. We then determined the variation in the seroprevalence among the troops. The numbers of seropositive individuals were $59,17,36,34$, and 34 , with a frequency of $68 \%, 55 \%, 63 \%, 56 \%$, and $77 \%$, respectively, for each troop (Table 1). In addition, the rearing population density in the free-range facility differed in each troop but was not correlated with the seroprevalence, suggesting that the density did not influence the high STLV-1 prevalence (Table 1).

We hypothesized that a substantial proportion of STLV-1-infected JMs might play a critical role as viral super-spreaders for frequent horizontal transmission and eventual high prevalence of STLV-1, possibly because of their abnormally high viral loads and poor humoral immune response against STLV-1. In fact, our recent incidence of an outbreak of infectious malignant

Table 1 Seroprevalence in JMs and other parameters having the possibilities of affecting seroprevalence in each troop

\begin{tabular}{lllllll}
\hline & Troop A & Troop B & Troop C & Troop D & Troop E & Total \\
\hline $\begin{array}{l}\text { Number of individuals } \\
\text { STLV-1 seroprevalence } \\
\quad \begin{array}{c}\text { (Number of infected/unin- } \\
\text { fected individuals) }\end{array}\end{array}$ & 87 & 31 & 57 & 61 & 44 & 280 \\
$\quad$ Age in average & 5.7 & $55 \%(17 / 14)$ & $63 \%(36 / 21)$ & $56 \%(34 / 27)$ & $77 \%(34 / 10)$ & $64 \%(180 / 100)$ \\
$\quad$ Rearing area $\left(\mathrm{m}^{2}\right)$ & 8500 & 4.5 & 4.2 & 6.5 & 5.0 & 5.5 \\
Area per individuals $\left(\mathrm{m}^{2}\right)$ & 97.7 & 109.7 & 850 & 730 & 1200 & 14,680 \\
\hline
\end{tabular}


thrombocytopenia in JMs by simian retrovirus type 4 (SRV-4) demonstrated that some of the monkeys developed asymptomatic SRV-4 infection with persistent viremia in the absence of SRV-4-specific antibody response and became viral super-spreaders [54, 55]. Taking this unexpected result into account, we evaluated ABTs and PVLs in the JM cohort. We found that the ABTs among 180 seropositive macaques were normally distributed with a geometric mean of 4076 and an ABT of 8192 at the maximum number of individuals (Fig. 1a, Additional file 1: Figure S1). We observed no significant difference in the titers among the five troops (Fig. 1b). We also examined the STLV-1 PVLs in PBMC samples and found that the PVLs of 171 proviral DNA-positive macaques were normally distributed and ranged from 0.01 to $20 \%$ with a geometric mean of $0.62 \%$ and PVLs from 0.64 to $1.28 \%$ at the maximum number of individuals (Fig. 2a, Additional file 2: Figure S2). Again, we observed no significant difference in the PVLs among the troops (Fig. 2b). The data regarding ABTs and PVLs from the 183 macaques positive for either value (herein tentatively regarded as 'STLV-1-infected') were plotted as shown in Fig. 3. Among the JMs, 168 were positive for both values, whereas three were negative for ABTs but positive for PVLs and 12 were positive for ABTs but negative for PVLs. Among the STLV-1-infected macaques,
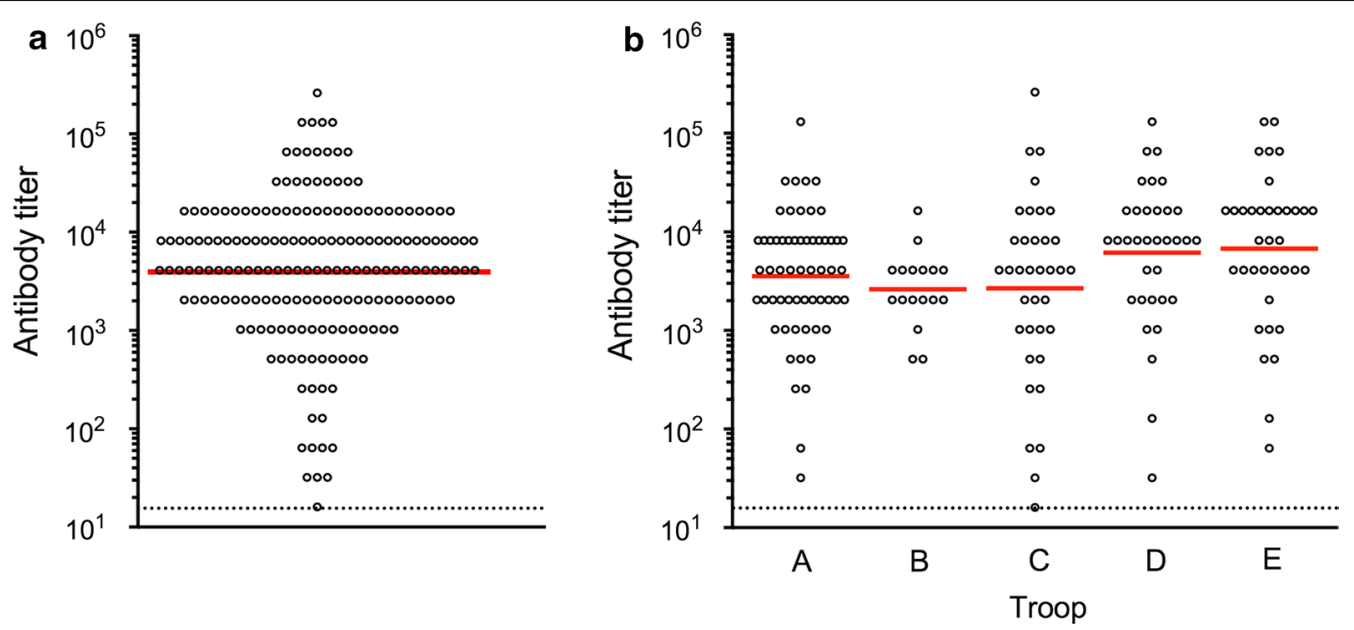

Fig. 1 Distribution of anti-STLV-1 antibody titers (ABTs) in seropositive JMs. Distribution of ABTs in all seropositive cohorts JMs (a) and in each troop (b) is indicated. The dotted line shows the detection limit of the ABT (16), and the red line indicates the geometric mean of the ABT distribution
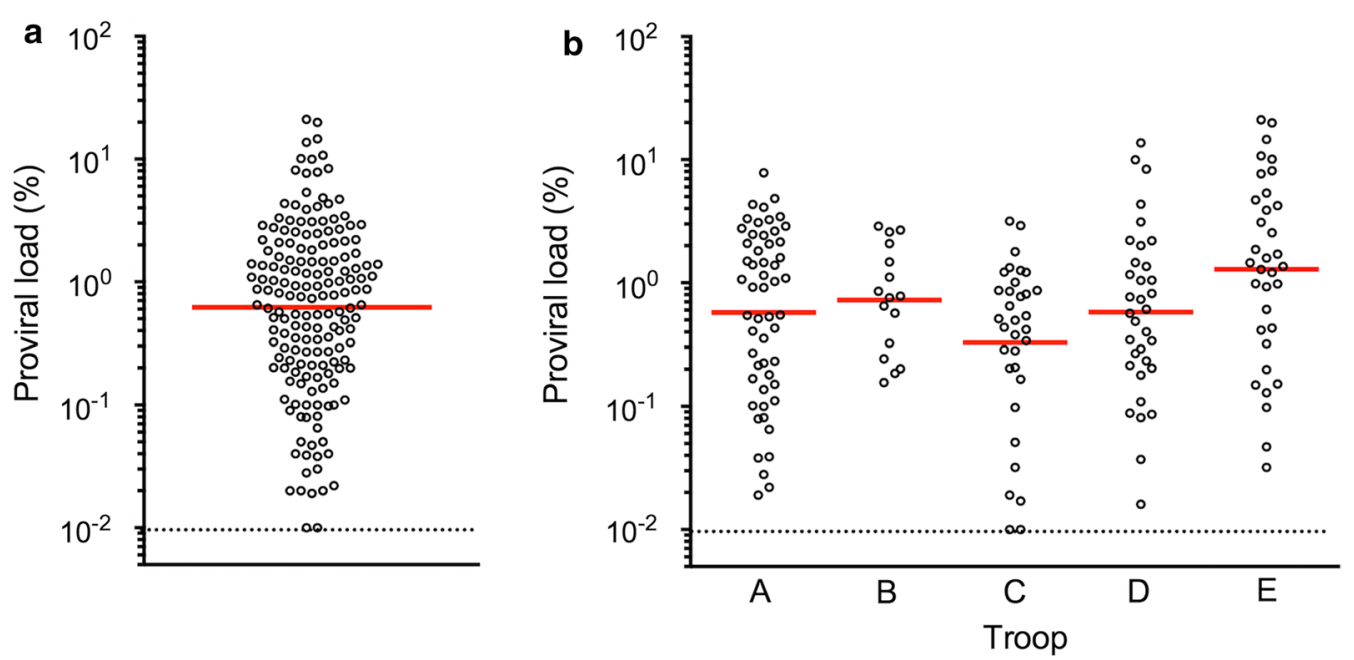

Fig. 2 Distribution of proviral loads (PVLs). Distribution of STLV-1 PVLs in all proviral DNA-positive cohorts JMs (a) and in each troop (b) is shown The dotted line indicates the detection limit of the PVL $(0.01 \%)$, and the horizontal line indicates the geometric mean of the PVL distribution 


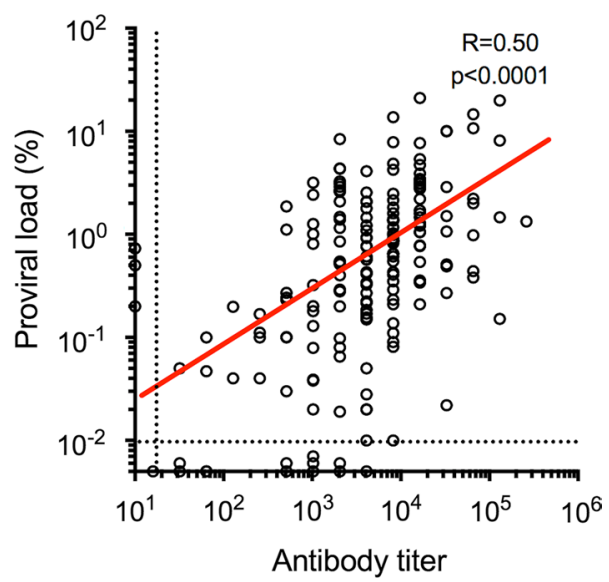

Fig. 3 Correlation between antibody titers (ABTs) and proviral loads (PVLs) among individuals who were positive for either value. Among the JMs $(N=183), 168$ were positive for both values, whereas three were seronegative but positive for PVLs, and 12 were seropositive but negative for PVLs. The horizontal and vertical dotted lines show the detection limits of PVL and ABT, respectively, as indicated in Figs. 1, 2. There was a significant correlation between the ABTs and the PVLs $(R=0.50 ; p<0.0001)$

we did not observe any individuals with abnormally high PVLs and poor ABTs (Fig. 3). It is notable that the three $\mathrm{ABT}^{-} \mathrm{PVL}^{+}$monkeys belonged to either of two troops (two macaques in troop $\mathrm{C}$ and one in troop $\mathrm{D}$ ), and their PVLs were comparable or less than the mean PVLs. It is therefore unlikely that only three monkeys caused the high prevalence in all the independent troops. Rather, we observed positive correlation between ABTs and PVLs $(R=0.50, p<0.0001)$ (Fig. 3), suggesting that humoral immunity was properly induced in response to the increasing proviral loads in these macaques.

We then sought the possible route(s) of transmission by which this high prevalence occurred. It was previously reported the age-related increase of STLV-1 prevalence in JMs, suggesting the frequent horizontal transmission whereas the mode of transmission remains to be elucidated [41, 43, 44, 52]. If mother-to-child transmission (MTCT) were the main route, the infection rate should drastically increase at around 1 year of age, followed by a gradual increase with age. On the other hand, if horizontal transmission were the main route, the infection rate should be low in younger ages, followed by a steep increase with age. To verify these possibilities, we examined the age-dependent change of seroprevalence in the cohort. The frequencies of seropositive individuals in each age group were $17 \%, 33 \%, 58 \%, 79 \%, 93 \%$, $100 \%$, and $95 \%$ at age groups of $0,1,2,3-5,6-8,9-11$, and $\geq 12$ years, respectively (Table 2 ). We also analyzed the age-dependent change of proviral DNA prevalence and found that the frequencies of proviral DNA-positive individuals in each age group were $11 \%, 31 \%, 58 \%$, $75 \%, 89 \%, 98 \%$, and $91 \%$ for the respective age groups (Table 2). The infection rate was over $30 \%$ at 1 year of age and was dramatically increased over $50 \%$ at the age of 2 years, over $70 \%$ at the ages of $3-5$ years, followed by infection among almost all of them over 9 years of age, irrespective of the either value of positivity. Considering that the rate of MTCT in the case of long-term breastfeeding is approx. $20 \%$ when the children of 3 years old and over of HTLV-1 carrier mothers were tested [56], these results appeared that STLV-1 may be frequently transmitted via both maternal and horizontal routes. Of note, large numbers of younger JMs with relatively low prevalence (i.e., among $280 \mathrm{JMs}$ cohort, $102 \mathrm{JMs}$ were $0-1$ years of age) reduced the apparent prevalence rate of the entire cohort (64\%), although almost all the adult JMs elder than 9 years of age were positive (Table 2). In addition, there was no significant difference among troops regarding ABTs and PVLs (data not shown). We also examined the dynamics of the ABTs and PVLs with age among the STLV-1-infected JMs. It was found that the ABTs and PVLs were gradually increased from 0 to 2 years of age, followed by a slight increase of ABTs and mostly stable PVLs with age (Table 2).

Table 2 Age-dependent changes of the prevalence of anti-STLV-1 antibody and provirus DNA in JMs

\begin{tabular}{llcccccc}
\hline Age & $\begin{array}{l}\text { Number of JMs } \\
\text { examined }\end{array}$ & $\begin{array}{l}\text { Number } \\
\text { of seropositive }\end{array}$ & Seropositive \% & $\begin{array}{l}\text { Geometric mean } \\
\text { of antibody titer }\end{array}$ & $\begin{array}{l}\text { Number of PVL- } \\
\text { positive }\end{array}$ & $\begin{array}{l}\text { Proviral DNA- } \\
\text { positive \% }\end{array}$ & $\begin{array}{l}\text { Geometric } \\
\text { mean of PVL }\end{array}$ \\
\hline 0 & 54 & 9 & 17 & 93 & 6 & 11 & 0.046 \\
1 & 48 & 16 & 33 & 2048 & 15 & 31 & 0.42 \\
2 & 31 & 18 & 58 & 2702 & 18 & 58 & 0.74 \\
$3-5$ & 28 & 22 & 79 & 3846 & 21 & 75 & 0.53 \\
$6-8$ & 27 & 25 & 93 & 3769 & 24 & 89 & 0.38 \\
$9-11$ & 48 & 48 & 100 & 5087 & 47 & 98 & 0.54 \\
$12 \leq$ & 44 & 42 & 95 & 6619 & 40 & 91 & 1.2 \\
Total & 280 & 180 & 64 & & 171 & 62 & \\
\hline
\end{tabular}


Results described above suggested that STLV-1 was frequently transmitted via both maternal and horizontal routes. However, it is still possible to speculate that the JMs of long-term (e.g. more than 3 years old) latent MTCT but not horizontal transmission might gradually convert to be positive, which led to the result as shown in Table 2. In order to validate this possibility, we conducted a retrospective study of the STLV-1 seroprevalence in this cohort. First, the cohort during the period from 2011 to 2012 was examined for the seroprevalence and found that 224 of $366 \mathrm{JMs}$ (61\%) were seropositive (PBMC samples during this period were not available), which was mostly comparable with the result during the period from 2015 to 2016 (64\%) as shown in Table 1 . We then selected 139 monkeys whose plasma samples were available in both periods. In 2011-2012, 111 of 139 JMs were seropositive, whereas 28 were seronegative. Four years later, $24(86 \%)$ of the seronegative 28 monkeys in the former period were seroconverted for the antibody (Table 3). Remarkably, among ten seronegative monkeys of 4 years of age and older (i.e., sexually mature monkeys) during the period from 2011 to 2012, eight were seroconverted within 4 years interval $(80 \%)$, which was comparable with the monkeys of 3 years of age and younger (i.e., sexually immature monkeys) in the former period (16/18, $89 \%)$. Although seroconversion occurred mostly in the younger ages, the frequency of seroconversion between the seronegative immature and mature monkeys was comparable (89\% and $80 \%$, respectively), which was consistent with the results shown in Table 2 . These results strongly suggest frequent STLV-1 transmission occurring among JMs via both horizontal and maternal transmission routes.

Table 3 Longitudinal study of the STLV-1 seroprevalence in JMs

\begin{tabular}{lccl}
\hline $\begin{array}{l}\text { Age in } 2011 \\
\text { (Age } \\
\text { in 2015) }\end{array}$ & $\begin{array}{l}\text { Number } \\
\text { of seronegative } \\
\text { in } \mathbf{2 0 1 1}\end{array}$ & $\begin{array}{l}\text { Number } \\
\text { of seropositive } \\
\text { in } \mathbf{2 0 1 5}\end{array}$ & $\begin{array}{l}\text { Frequency } \\
\text { of seroconversion }\end{array}$ \\
\hline $0(4)$ & 7 & 6 & \\
$1(5)$ & 1 & 1 & \\
$2(6)$ & 6 & 6 & \\
$3(7)$ & 4 & 3 & $16 / 18(89 \%)$ \\
$0-3(4-7)$ & 18 & 16 & \\
$4(8)$ & 3 & 3 & \\
$5(9)$ & 1 & 1 & $8 / 10(80 \%)$ \\
$6(10)$ & 3 & 3 & $24 / 28(86 \%)$ \\
$\geq 7(\geq 11)$ & 3 & 1 & \\
$\geq 4(\geq 8)$ & 10 & 8 & \\
Total & 28 & 24 & \\
\hline
\end{tabular}

It has been shown that a certain degree of heterogeneity of HTLV-1 genome was present among the virusinfected individuals in the same community $[57,58]$ while the heterogeneity of the viral genome between mother and child was minimal [59-65]. If it is the case with STLV-1-infected JMs, then it could be possible to differentiate whether the STLV-1 infected in a monkey is derived from mother through MTCT or from any other monkeys through horizontal transmission. In order to examine the possibility, we compared the nucleotide sequences of STLV-1 LTR, tax and env regions from randomized 12 JMs in a troop D as a representative. It was found that almost all the sequences of $3^{\prime}$ LTR and env region were identical in all the monkeys except for only a unique heterogeneity in some monkeys (for 3'LTR: C333G for A1671; G346A for A2594, for env: T1218C for 8 monkeys, respectively) (Additional file 3: Figure S3a, c). Furthermore, no heterogeneity was observed in the tax region of all monkeys (Additional file 3: Figure S3b). These results indicated that STLV-1 genome was highly conserved among the JMs in the troop, with consistent results in terms of other troops (Kuramitsu et al. unpublished observation). Consequently, it was not possible to determine the transmission route of STLV-1 on the basis of the heterogeneity of the virus genome, which was unlike HTLV-1.

\section{Discussion}

In this study, we aimed to investigate the epidemiological background by which STLV-1 infection is highly prevalent in JMs. We initially examined the prevalence of STLV-1 infection in five independent troops of $280 \mathrm{JMs}$ originating from different areas in Japan. It was found that $64 \%(180 / 280)$ of the macaques were seropositive, which was generally consistent with previous reports [41, 43, 44, 52] (Table 1). Second, the ABTs and PVLs in the STLV-1-infected JMs were normally distributed with mean values of 4076 and $0.62 \%$, respectively, which were mostly comparable to those of HTLV-1-infected humans (Figs. 1, 2). As no macaques exhibiting abnormally high PVLs together with poor ABTs were observed, our initial hypothesis that a small proportion of JMs might be the viral super-spreaders was unlikely (Fig. 3). Third, the frequency of STLV-1 infection was over $50 \%$ at the age of 2 years, irrespective of the either value of positivity (Table 2), suggesting the possibility of greater frequency of MTCT as compared with humans. Finally, our retrospective study indicated that frequent seroconversion occurred in not only younger (until 3 years of age, sexually immature) but also older (4 years of age and over, sexually mature) seronegative monkeys (Table 3). Together with the fact that almost all of the full-adult JMs older than 9 years old were infected with STLV-1, our results 
of this study demonstrated for the first time that frequent horizontal and mother-to-child transmission may contribute to high prevalence of STLV-1 infection in JMs.

Contrary to our speculation, we did not observe the JMs exhibiting aberrant ABTs and PVLs who might contribute to frequent STLV-1 transmission as superspreaders. It is therefore reasonable to consider that immunological abnormality of a subpopulation of JMs may not be attributed to the high prevalence of STLV1. It was also possible to assume that the environmental condition in which the JMs in our animal facility might be, at least in part, associated with the high prevalence. In this point of view, the rearing population density was not correlated with the seroprevalence of each troop (Table 1), suggesting that the density did not influence the high prevalence. Moreover, we recently examined the plasma samples of the JMs stored at the quarantine procedure when they were previously introduced in our facility and found that the STLV-1 seroprevalence of them was generally comparable with that of the JMs in the breeding facility as shown in this study (data not shown), indicating the high prevalence of JMs by nature as previously reported [41, 43, 44, 52].

It has been shown that JMs genetically originate in rhesus macaques (RMs) as the ancestor macaques came over from the Asian Continent to Japan around 0.5 million years ago [66] and that much less frequency of RMs are infected with STLV-1 than the case of JMs [67], which is consistent with the fact that the prevalence rate of STLV-1 in RMs bred and reared in our free-range facility is less than 1\% [52]. It is therefore reasonable to speculate that STLV-1 was broadly disseminated after ancestor macaques started inhabiting Japan. As for the migrated JMs, foods such as leaves, fruits, and nuts in their habitats were insufficient in the cold winter season so they probably needed to form troops in order to keep their territories for foods and to stay warm by assembling together [68]. Interestingly, RMs are promiscuous in terms of mating [69], as JMs do so without having fixed partners/mates, which may circumvent the genetic disadvantages caused by inbreeding within the troop [70]. It is possible that promiscuity together with the tight troop society might increase the opportunity of sexual transmission, which led to the high STLV-1 prevalence in JMs. In fact, it was reported that a relatively high prevalence of HTLV-1 was occasionally observed in isolated Japanese populations [71] and in Noir-Marron isolated population in French Guiana [72]. Alternatively, severe contact due to fights among the macaques regardless of gender may also be the additional cause of the horizontal transmission.

It was found that the rates of seropositive and proviral DNA-positive JMs were $17 \%$ and $11 \%$, respectively
(Table 2). The reason that the former was greater than the latter may be the inclusion of the individuals that were still positive for maternal antibody without STLV-1 infection-induced seroconversion. Subsequently, the frequency of STLV-1 infection was over $30 \%$ at the age of 1 year and over $50 \%$ at the age of 2 years, respectively, as observed in either value (Table 2). These rates were much higher than the case of humans, suggesting that MTCT may occur frequently in JMs. JMs usually breastfeed around 1 year, while some of the mothers feed longer period up to 1.5 years,which is generally comparable with humans. It is therefore reasonable to consider that the length of the infant period may not be the reason for the high MTCT rate. It is also unclear yet whether MTCT is solely responsible for the steep increase in the rate of STLV-1 infection among the younger monkeys until 2 years of ages or not only MTCT but also horizontal transmission due to fighting would contribute to the increase. The longitudinal study of MTCT in a cohort of mother-baby pairs isolated from other monkeys may answer the question.

\section{Conclusion}

Our results of this study demonstrated for the first time that frequent horizontal and mother-to-child transmission may contribute to high prevalence of STLV-1 infection in JMs.

\section{Supplementary information}

\section{Supplementary information accompanies this paper at https://doi. org/10.1186/s12977-020-00525-1.}

Additional file 1: Figure S1 Distribution of anti-STLV-1 antibody titers (ABTs) in seropositive JMs. The $X$-axis represents antibody titers ranging from 16-262144, with an ABT of 8192 at the maximum number of individuals. The $Y$-axis represents the number of individuals in each antibody titer.

Additional file 2: Figure S2. Distribution of STLV-1 proviral loads (PVLS) in the JMs positive for STLV-1 proviral DNA. The X-axis indicates PVLs ranging from $0.01 \%-20 \%$, with PVLs of $0.64 \%-1.28 \%$ at the maximum number of individuals. The $Y$-axis shows the number of individuals in each $P V L$ group.

Additional file 3: Figure S3 a, b and c. Alignments of the STLV-1 partial nucleotide sequences in a JM troop. Total of 12 proviral DNA-positive JMs in troop D were examined as a representative (age ranges: 2-21 years of age; sex: 4 male and 8 female) for the viral sequences of first 600 nucleotides of STLV-1 3'LTR (a) and tax exon3 (b) as well as 1447 nucleotides of entire STLV-1 env (c) by direct sequencing. The results of the alignments demonstrated only one nucleotide variation in both 3'LTR and env but not tax exon3 region for each JMs.

\section{Abbreviations}

STLV-1: Simian T-cell leukemia virus type 1; HTLV-1: Human T-cell leukemia virus type 1; JM: Japanese macaque; PBMCs: Peripheral blood mononuclear cells; ABT: Antibody titer; PVL: Proviral load; ATL: Adult T-cell leukemia; HAM/ TSP: HTLV-1-associated myelopathy/tropical spastic paraparesis; MTCT : Mother-to-child transmission; PA: Particle-agglutination; KUPRI: Kyoto 
University Primate Research Institute; SRV-4: Simian retrovirus type 4; RM: Rhesus macaque.

\section{Acknowledgements}

The blood samples of JMs used in this study were partly provided by National Bio-Resource Project "Japanese Monkey" of MEXT, Japan. We thank Kaoru Tsuji and colleagues of Center for Human Evolution Modeling Research in KUPRI for their technical assistance. We also thank Goro Hanya for valuable information regarding ecology of Japanese macaques.

\section{Authors' contributions}

MM designed and performed the experiments, analyzed the data, and wrote the manuscript. JY, MK, KO, IH, TM, and MM performed the experiments and analyzed the data. AW, YS, WKT and AH were involved in sample and data collection. HA supervised the research and wrote the paper. All authors read and approved the final manuscript.

\section{Funding}

This research was supported by AMED under Grant Number 18fk0108059h0201 and 19cm0106365h0001.

\section{Availability of data and materials}

The datasets used and/or analyzed during the current study are available from the corresponding author on reasonable request.

\section{Ethics approval and consent to participate}

All animal experiments were approved by the Animal Welfare and Animal Care Committee of KUPRI (approval numbers: 2014-092, 2015-040, and 2016-135) and were conducted in accordance with the Guidelines for Care and Use of Nonhuman Primates (Version 3) by the Animal Welfare and Animal Care Committee of KUPRI.

\section{Consent for publication}

Not applicable.

\section{Competing interests}

The authors declare that they have no competing interests.

\section{Author details}

${ }^{1}$ Center for Human Evolution Modeling Research, Primate Research Institute, Kyoto University, 41-2 Kanrin, Inuyama 484-8506, Japan. ${ }^{2}$ Laboratory of Virus Control, Institute for Frontier Life and Medical Sciences, Kyoto University, 53 Shogoin-Kawahara-cho, Sakyo-ku, Kyoto 606-8507, Japan. ${ }^{3}$ Department of Hematology, Rheumatology and Infectious Disease, Graduate School of Medical Sciences, Kumamoto University, 1-1-1 Honjo Chuo-ku, Kumamoto 860-8556, Japan. ${ }^{4}$ Department of Safety Research on Blood and Biological Products, National Institute of Infectious Diseases, 4-7-1 Gakuen, Musashimurayama, Tokyo 208-0011, Japan. ${ }^{5}$ Laboratory of Infectious Disease Model, Institute for Frontier Life and Medical Sciences, Kyoto University, 53 Shogoin-Kawahara-cho, Sakyo-ku, Kyoto 606-8507, Japan.

Received: 11 April 2020 Accepted: 16 June 2020

Published online: 23 June 2020

\section{References}

1. Poiesz BJ, Ruscetti FW, Gazdar AF, Bunn PA, Minna JD, Gallo RC. Detection and isolation of type $C$ retrovirus particles from fresh and cultured lymphocytes of a patient with cutaneous T-cell lymphoma. Proc Natl Acad Sci USA. 1980;77:7415-9.

2. Yoshida M, Miyoshi I, Hinuma Y. Isolation and characterization of retrovirus from cell lines of human adult T-cell leukemia and its implication in the disease. Proc Natl Acad Sci USA. 1982;79:2031-5.

3. Uchiyama T, Yodoi J, Sagawa K, Takatsuki K, Uchino H. Adult T-cell leukemia: clinical and hematologic features of 16 cases. Blood. 1977;50:481-92.

4. Gessain A, Barin F, Vernant JC, Gout O, Maurs L, Calender A, de The G. Antibodies to human T-lymphotropic virus type-l in patients with tropical spastic paraparesis. Lancet. 1985;326:407-10.
5. Hirose S, Uemura Y, Fujishita M, Kitagawa T, Yamashita M, Imamura J, Ohtsuki Y, Taguchi H, Miyoshi I. Isolation of HTLV-I from cerebrospinal fluid of a patient with myelopathy. Lancet. 1986;328:397-8.

6. Osame M, Usuku K, Izumo S, Ijichi N, Amitani H, Igata A, Matsumoto M, Tara M. HTLV-I associated myelopathy, a new clinical entity. Lancet. 1986;327:1031-2.

7. Gessain A, Cassar O. Epidemiological aspects and world distribution of HTLV-1 infection. Front Microbiol. 2012;3:388.

8. Edlich RF, Arnette JA, Williams FM. Global epidemic of human T-cell lymphotropic virus type-I (HTLV-I). J Emerg Med. 2000;18:109-19.

9. Tajima K. The 4th nation-wide study of adult T-cell leukemia/lymphoma (ATL) in Japan: estimates of risk of ATL and its geographical and clinical features. The T- and B-cell Malignancy Study Group. Int J Cancer. 1990;45:237-43.

10. Satake M, Yamaguchi K, Tadokoro K. Current prevalence of HTLV-1 in Japan as determined by screening of blood donors. J Med Virol. 2012;84:327-35.

11. Shimoyama M. Diagnostic criteria and classification of clinical subtypes of adult T-cell leukaemia-lymphoma. A report from the Lymphoma Study Group (1984-87). Br J Haematol. 1991;79:428-37.

12. Takatsuki K. Discovery of adult T-cell leukemia. Retrovirology. 2005;2:16.

13. Goncalves DU, Proietti FA, Ribas JG, Araujo MG, Pinheiro SR, Guedes AC, Carneiro-Proietti AB. Epidemiology, treatment, and prevention of human T-cell leukemia virus type 1-associated diseases. Clin Microbiol Rev. 2010;23:577-89.

14. Kamoi K, Mochizuki M. HTLV infection and the eye. Curr Opin Ophthalmol. 2012;23:557-61.

15. Ishitsuka K, Tamura K. Human T-cell leukaemia virus type I and adult T-cell leukaemia-lymphoma. Lancet Oncol. 2014;15:e517-26.

16. McKendall RR. Neurologic disease due to HTLV-1 infection. In: Tselis AC, Booss J, editors. Handbook of Clinical Neurology, vol. 123. Oxford: Elsevier; 2014. p. 507-30.

17. Bangham CR, Araujo A, Yamano Y, Taylor GP. HTLV-1-associated myelopathy/tropical spastic paraparesis. Nat Rev Dis Primers. 2015;1:15012.

18. Bangham CR, Ratner L. How does HTLV-1 cause adult T-cell leukaemia/ lymphoma (ATL)? Curr Opin Virol. 2015;14:93-100.

19. Ishikawa K, Fukasawa M, Tsujimoto H, Else JG, Isahakia M, Ubhi NK, Ishida T, Takenaka O, Kawamoto Y, Shotake T, et al. Serological survey and virus isolation of simian T-cell leukemia/T-lymphotropic virus type I (STLV-I) in non-human primates in their native countries. Int J Cancer. 1987;40:233-9.

20. Koralnik IJ, Boeri E, Saxinger WC, Monico AL, Fullen J, Gessain A, Guo HG, Gallo RC, Markham P, Kalyanaraman V, et al. Phylogenetic associations of human and simian T-cell leukemia/lymphotropic virus type I strains: evidence for interspecies transmission. J Virol. 1994;68:2693-707.

21. Ibuki K, Ido E, Setiyaningsih S, Yamashita M, Agus LRP, Takehisa J, Miura T, Dondin S, Hayami M. Isolation of STLV-I from orangutan, a great ape species in Southeast Asia, and its relation to other HTLV-IS/STLV-Is. Jpn J Cancer Res. 1997;88:1-4.

22. Verschoor EJ, Warren KS, Niphuis H, Heriyanto, Swan RA, Heeney JL. Characterization of a simian T-lymphotropic virus from a wild-caught orang-utan (Pongo pygmaeus) from Kalimantan, Indonesia. J Gen Virol. 1998;79:51-5.

23. Jegado B, Kashanchi F, Dutartre H, Mahieux R. STLV-1 as a model for studying HTLV-1 infection. Retrovirology. 2019;16:41.

24. Watanabe T, Seiki M, Tsujimoto H, Miyoshi I, Hayami M, Yoshida M. Sequence homology of the simian retrovirus genome with human T-cell leukemia virus type I. Virology. 1985;144:59-65.

25. Digilio L, Giri A, Cho N, Slattery J, Markham P, Franchini G. The simian T-lymphotropic/leukemia virus from Pan paniscus belongs to the type 2 family and infects Asian macaques. J Virol. 1997;71:3684-92.

26. Van Brussel M, Salemi M, Liu HF, Gabriels J, Goubau P, Desmyter J, Vandamme AM. The simian T-lymphotropic virus STLV-PP1664 from Pan paniscus is distinctly related to HTLV-2 but differs in genomic organization. Virology. 1998;243:366-79.

27. Meertens L, Mahieux R, Mauclere P, Lewis J, Gessain A. Complete sequence of a novel highly divergent simian T-cell lymphotropic virus from wild-caught red-capped mangabeys (Cercocebus torquatus) from Cameroon: a new primate T-lymphotropic virus type 3 subtype. J Virol. 2002;76:259-68. 
28. Meertens $L$, Gessain A. Divergent simian T-cell lymphotropic virus type 3 (STLV-3) in wild-caught Papio hamadryas papio from Senegal: widespread distribution of STLV-3 in Africa. JVirol. 2003;77:782-9.

29. LeBreton M, Switzer WM, Djoko CF, Gillis A, Jia H, Sturgeon MM, Shankar A, Zheng H, Nkeunen G, Tamoufe U, et al. A gorilla reservoir for human T-lymphotropic virus type 4. Emerg Microbes Infect. 2014;3:e7.

30. Tsujimoto H, Noda Y, Ishikawa K, Nakamura H, Fukasawa M, Sakakibara I, Sasagawa A, Honjo S, Hayami M. Development of adult T-cell leukemialike disease in African green monkey associated with clonal integration of simian T-cell leukemia virus type I. Cancer Res. 1987;47:269-74.

31. Voevodin A, Samilchuk E, Schatzl H, Boeri E, Franchini G. Interspecies transmission of macaque simian T-cell leukemia/lymphoma virus type 1 in baboons resulted in an outbreak of malignant lymphoma. J Virol. 1996;70:1633-9.

32. Akari H, Ono F, Sakakibara I, Takahashi H, Murayama Y, Hiyaoka A, Terao K, Otani I, Mukai R, Adachi A, Yoshikawa Y. Simian T cell leukemia virus type I-induced malignant adult T cell leukemia-like disease in a naturally infected African green monkey: implication of CD8 +T cell leukemia. AIDS Res Hum Retroviruses. 1998;14:367-71.

33. Turpin J, Alais S, Marcais A, Bruneau J, Melamed A, Gadot N, Tanaka Y, Hermine $\mathrm{O}$, Melot $\mathrm{S}$, Lacoste $\mathrm{R}$, et al. Whole body clonality analysis in an aggressive STLV-1 associated leukemia (ATLL) reveals an unexpected clonal complexity. Cancer Lett. 2017;389:78-85.

34. Slattery JP, Franchini G, Gessain A. Genomic evolution, patterns of global dissemination, and interspecies transmission of human and simian T-cell leukemia/lymphotropic viruses. Genome Res. 1999;9:525-40.

35. Locatelli S, Peeters M. Cross-species transmission of simian retroviruses: how and why they could lead to the emergence of new diseases in the human population. AIDS. 2012;26:659-73.

36. Filippone C, Betsem E, Tortevoye P, Cassar O, Bassot S, Froment A, Fontanet $A$, Gessain A. A severe bite from a nonhuman primate is a major risk factor for HTLV-1 infection in hunters from central Africa. Clin Infect Dis. 2015;60:1667-76.

37. Kazanji M, Mouinga-Ondeme A, Lekana-Douki-Etenna S, Caron M, Makuwa M, Mahieux R, Gessain A. Origin of HTLV-1 in hunters of nonhuman primates in Central Africa. J Infect Dis. 2015;211:361-5.

38. Mossoun A, Calvignac-Spencer S, Anoh AE, Pauly MS, Driscoll DA, Michel AO, Nazaire LG, Pfister S, Sabwe P, Thiesen U, et al. Bushmeat hunting and zoonotic transmission of simian T-Lymphotropic Virus 1 in Tropical West and Central Africa. J Virol. 2017;91:e02479.

39. Song KJ, Nerurkar VR, Saitou N, Lazo A, Blakeslee JR, Miyoshi I, Yanagihara R. Genetic analysis and molecular phylogeny of simian T-cell lymphotropic virus type l: evidence for independent virus evolution in Asia and Africa. Virology. 1994;199:56-66.

40. Gallo RC, Sliski A, Wong-Staal F. Origin of human T-cell leukaemia-lymphoma virus. Lancet. 1983;322:962-3.

41. Hayami M, Komuro A, Nozawa K, Shotake T, Ishikawa K, Yamamoto K, Ishida T, Honjo S, Hinuma Y. Prevalence of antibody to adult T-cell leukemia virus-associated antigens (ATLA) in Japanese monkeys and other non-human primates. Int J Cancer. 1984;33:179-83.

42. Miura T, Fukunaga T, Igarashi T, Yamashita M, Ido E, Funahashi S, Ishida T, Washio K, Ueda S, Hashimoto K, et al. Phylogenetic subtypes of human T-lymphotropic virus type I and their relations to the anthropological background. Proc Natl Acad Sci USA. 1994;91:1124-7.

43. Ishida T, Yamamoto K, Kaneko R, Tokita E, Hinuma Y. Seroepidemiological study of antibodies to adult T-cell leukemia virus-associated antigen (ATLA) in free-ranging Japanese monkeys (Macaca fuscata). Microbiol Immunol. 1983;27:297-301.

44. Miyoshi I, Fujishita M, Taguchi H, Matsubayashi K, Miwa N, Tanioka Y. Natural infection in non-human primates with adult T-cell leukemia virus or a closely related agent. Int J Cancer. 1983;32:333-6.

45. Saksena NK, Herve V, Durand JP, Leguenno B, Diop OM, Digouette JP, Mathiot C, Muller MC, Love JL, Dube S, et al. Seroepidemiologic, molecular, and phylogenetic analyses of simian T-cell leukemia viruses (STLV-I) from various naturally infected monkey species from central and western Africa. Virology. 1994;198:297-310.

46. Nerrienet E, Meertens L, Kfutwah A, Foupouapouognigni Y, Gessain A. Molecular epidemiology of simian T-lymphotropic virus (STLV) in wildcaught monkeys and apes from Cameroon: a new STLV-1, related to human T-lymphotropic virus subtype F, in a Cercocebus agilis. J Gen Virol. 2001;82:2973-7.
47. Takemura T, Yamashita M, Shimada MK, Ohkura S, Shotake T, Ikeda M, Miura T, Hayami M. High prevalence of simian T-Lymphotropic virus type L in wild ethiopian baboons. JVirol. 2002;76:1642-8.

48. Andrade MR, Yee J, Barry P, Spinner A, Roberts JA, Cabello PH, Leite JP, Lerche NW. Prevalence of antibodies to selected viruses in a long-term closed breeding colony of rhesus macaques (Macaca mulatta) in Brazil. Am J Primatol. 2003;59:123-8.

49. Courgnaud V, Van Dooren S, Liegeois F, Pourrut X, Abela B, Loul S, Mpoudi-Ngole E, Vandamme A, Delaporte E, Peeters M. Simian T-Cell leukemia virus (STLV) infection in wild primate populations in cameroon: evidence for dual STLV type 1 and type 3 infection in agile mangabeys (Cercocebus agilis). JVirol. 2004;78:4700-9.

50. Mee ET, Murrell CK, Watkins J, Almond N, Cutler K, Rose NJ. Low rates of transmission of SRV-2 and STLV-I to juveniles in a population of Macaca fascicularis facilitate establishment of specific retrovirus-free colonies. J Med Primatol. 2009;38:160-70.

51. Eguchi K, Ohsawa K, Fuse-Kiyono M, Suzuki J, Kurokawa K, Yamamoto T. Short communication: epidemiological evidence that simian T-lymphotropic virus type 1 in Macaca fuscata has an alternative transmission route to maternal infection. AIDS Res Hum Retroviruses. 2011;27:113-4.

52. Miura M, Yasunaga J, Tanabe J, Sugata K, Zhao T, Ma G, Miyazato P, Ohshima K, Kaneko A, Watanabe A, et al. Characterization of simian T-cell leukemia virus type 1 in naturally infected Japanese macaques as a model of HTLV-1 infection. Retrovirology. 2013;10:118.

53. Ahuka-Mundeke S, Lunguya-Metila O, Mbenzo-Abokome V, Butel C, Inogwabini Bl, Omasombo V, Muyembe-Tamfum JJ, Georgiev AV, Muller MN, Ndjango JN, et al. Genetic diversity of STLV-2 and interspecies transmission of STLV-3 in wild-living bonobos. Virus Evol. 2016;2:vew011.

54. Cyranoski D. Japanese monkey deaths puzzle. Nature. 2010;466:302-3.

55. Okamoto M, Miyazawa T, Morikawa S, Ono F, Nakamura S, Sato E, Yoshida T, Yoshikawa R, Sakai K, Mizutani T, et al. Emergence of infectious malignant thrombocytopenia in Japanese macaques (Macaca fuscata) by SRV-4 after transmission to a novel host. Sci Rep. 2015;5:8850.

56. Nyambi PN, Ville Y, Louwagie J, Bedjabaga I, Glowaczower E, Peeters M, Kerouedan D, Dazza M, Larouze B, van der Groen G, Delaporte E. Motherto-child transmission of human T-cell lymphotropic virus types I and II (HTLV-I/II) in Gabon: a prospective follow-up of 4 years. J Acquir Immune Defic Syndr Hum Retrovirol. 1996;12:187-92.

57. Eirin ME, Berini CA, Jones LR, Dilernia DA, Puca AA, Biglione MM. Stable human T-cell lymphotropic virus type 1 (HTLV-1) subtype a/subgroup a endemicity in Amerindians from Northwest Argentina: a health problem to be resolved. J Med Virol. 2010;82:2116-22.

58. van Tienen C, de Silva TI, Alcantara LC, Onyango CO, Jarju S, Goncalves N, Vincent T, Aaby P, Whittle H, Schim van der Loeff M, Cotten M. Molecular epidemiology of endemic human T-lymphotropic virus type 1 in a rural community in Guinea-Bissau. PLoS Negl Trop Dis. 2012;6:e1690.

59. Major ME, Nightingale S, Desselberger U. Complete sequence conservation of the human T cell leukaemia virus type 1 tax gene within a family cluster showing different pathologies. J Gen Virol. 1993;74:2531-7.

60. Liu HF, Vandamme AM, Kazadi K, Carton H, Desmyter J, Goubau P. Familial transmission and minimal sequence variability of human T-lymphotropic virus type I (HTLV-I) in Zaire. AIDS Res Hum Retroviruses. 1994;10:1135-42.

61. Van Dooren S, Pybus OG, Salemi M, Liu HF, Goubau P, Remondegui C, Talarmin A, Gotuzzo E, Alcantara LC, Galvão-Castro B, Vandamme AM. The low evolutionary rate of human T-cell lymphotropic virus type-1 confirmed by analysis of vertical transmission chains. Mol Biol Evol. 2004:21:603-11.

62. Gastaldello R, Otsuki K, Barbas MG, Vicente AC, Gallego S. Molecular evidence of HTLV-1 intrafamilial transmission in a non-endemic area in Argentina. J Med Virol. 2005;76:386-90.

63. Martins RM, do Nascimento LB, Carneiro MA, Teles SA, Lopes CL, MottaCastro AR, Otsuki K, Vicente AC. HTLV-1 intrafamilial transmission through three generations in an isolated Afro-Brazilian community. J Clin Virol. 2010;48:155-7.

64. Frutos MC, Gastaldello R, Balangero M, Remondegui C, Blanco S, Otsuki K, Paulo Vicente AC, Elias D, Mangeaud A, Nates S, Gallego S. Silent dissemination of HTLV-1 in an endemic area of Argentina. Epidemiological and molecular evidence of intrafamilial transmission. PLoS One. 2017;12:e0174920.

65. Bandeira LM, Uehara SNO, Puga MAM, Rezende GR, Vicente ACP, Domingos JA, do Lago BV, Niel C, Motta-Castro ARC. HTLV-1 
intrafamilial transmission among Japanese immigrants in Brazil. J Med Virol. 2018;90:351-7.

66. Nozawa K, Shotake T, Ohkura Y, Tanabe Y. Genetic variations within and between species of Asian macaques. Jpn J Genet. 1977;52:15-30.

67. Daniel MD, Letvin NL, Sehgal PK, Schmidt DK, Silva DP, Solomon KR, Hodi FS Jr, Ringler DJ, Hunt RD, King NW, Desrosiers RC. Prevalence of antibodies to 3 retroviruses in a captive colony of macaque monkeys. Int J Cancer. 1988:41:601-8.

68. Anderson JR. Sleep-related behavioural adaptations in free-ranging anthropoid primates. Sleep Med Rev. 2000;4:355-73.

69. Lindburg DG. The rhesus monkey in North India: an ecological and behavioral study. In: Rosenblum LA, editor. Primate Behavior. Academic Press, vol. 2. Oxford: Elsevier; 1971. p. 1-106.

70. Fooden J, Aimi M. Systematic Review of Japanese Macaques, Macaca fuscata (Gray, 1870). Fieldiana Zoology. 2005;104:1-198.
71. Tachibana K, Ito S, Shirahama S, Nagatomo M, Kinoshita K, Tajima K. Epidemic patterns of hepatitis type B virus (HBV) and human T lymphotropic virus type I (HTLV-I) in two ATL-endemic islands in Kyushu. Japan. Nagoya J Med Sci. 1991;53:23-32.

72. Plancoulaine S, Buigues RP, Murphy EL, van Beveren M, Pouliquen JF, Joubert M, Remy F, Tuppin P, Tortevoye P, de The G, et al. Demographic and familial characteristics of HTLV-1 infection among an isolated, highly endemic population of African origin in French Guiana. Int J Cancer. 1998;76:331-6.

\section{Publisher's Note}

Springer Nature remains neutral with regard to jurisdictional claims in published maps and institutional affiliations.
Ready to submit your research? Choose BMC and benefit from:

- fast, convenient online submission

- thorough peer review by experienced researchers in your field

- rapid publication on acceptance

- support for research data, including large and complex data types

- gold Open Access which fosters wider collaboration and increased citations

- maximum visibility for your research: over $100 \mathrm{M}$ website views per year

At BMC, research is always in progress.

Learn more biomedcentral.com/submissions 